\title{
Marijke Metselaar. Die Nestorianer und der frühe Islam. Wechselwirkungen zwischen den ostsyrischen Christen und ihre arabischen Nachbarn
}

Florence Jullien

\section{OpenEdition}

Journals

Édition électronique

URL : http://journals.openedition.org/abstractairanica/40856

DOI : 10.4000/abstractairanica.40856

ISSN : 1961-960X

Éditeur :

CNRS (UMR 7528 Mondes iraniens et indiens), Éditions de l'IFRI

Édition imprimée

Date de publication : 1 décembre 2013

ISSN : 0240-8910

\section{Référence électronique}

Florence Jullien, « Marijke Metselaar. Die Nestorianer und der frühe Islam. Wechselwirkungen

zwischen den ostsyrischen Christen und ihre arabischen Nachbarn », Abstracta Iranica [En ligne],

Volume 32-33 | 2013, document 337, mis en ligne le 01 juillet 2016, consulté le 26 septembre 2020.

URL : http://journals.openedition.org/abstractairanica/40856 ; DOI : https://doi.org/10.4000/

abstractairanica.40856

Ce document a été généré automatiquement le 26 septembre 2020.

Tous droits réservés 


\section{Marijke Metselaar. Die Nestorianer und der frühe Islam. Wechselwirkungen zwischen den ostsyrischen Christen und ihre arabischen Nachbarn}

Florence Jullien

\section{RÉFÉRENCE}

Marijke Metselaar. Die Nestorianer und der frühe Islam. Wechselwirkungen zwischen den ostsyrischen Christen und ihre arabischen Nachbarn. Frankfurt, Peter Lang, 2009, 92 p. (Theion 23)

1 L'A. propose une réflexion sur les chrétiens syro-orientaux dans l'ancien empire perse au début de l'islam, s'intéressant en particulier aux questions de formation des élites et de la mission notamment auprès des tribus arabes voisines. À la suite du choix de Bagdad comme nouvelle capitale, les chrétiens se sont engagés dans des contacts fructueux avec les nouveaux dirigeants arabes; l'A. retrace ici les discussions comme les interactions entre les savants arabes et nestoriens, et l'on sait le rôle décisif que jouèrent ces derniers dans la transmission des savoirs, en particulier de l'héritage grec. 


\section{AUTEURS}

\section{FLORENCE JULLIEN}

EPHE, Paris 